\title{
Tyro3, Axl, and Mertk receptors differentially participate in platelet activation and thrombus formation
}

\author{
Junsong Zhou ${ }^{1 *}$, Aizhen Yang ${ }^{1}$, Yucan Wang ${ }^{1}$, Fengwu Chen ${ }^{1}$, Zhenzhen Zhao ${ }^{1}$, Viralkumar Davra², \\ Katsue Suzuki-Inoue ${ }^{3}$, Yukio Ozaki ${ }^{3}$, Raymond B. Birge ${ }^{2}$, Qingxian Lu ${ }^{4}$ and Yi Wu ${ }^{1,5^{*}}$
}

\begin{abstract}
Background: Previously, several studies have shown that Tyro3, Axl, and Mertk (TAM) receptors participate in platelet activation and thrombosis. However, the role of individual receptors is not fully understood.

Methods: Using single receptor-deficient platelets from TAM knockout mice in the C57BL/6 J strain, we performed a knockout study using single TAM-deficient mice. We treated platelets isolated from TAM knockout mice with the Glycoprotein VI (GPVI) agonists convulxin, poly(PHG), and collagen-related triple-helical peptide (CRP), as well as thrombin for in-vitro experiments. We used a laser-induced cremaster arterial injury model for thrombosis experiments in vivo.

Results: Deficiency of the tyrosine kinase receptors, Axl or Tyro3, but not Mertk, inhibited aggregation, spreading, JON/A binding, and P-selectin expression of platelets in vitro. In vivo, platelet thrombus formation was significantly decreased in $\mathrm{Axl}^{-/-}$and $\mathrm{Tyro}^{-/-}$mice, but not in $\mathrm{Mertk}^{-/-}$mice. Upon stimulation with glycoprotein VI (GPVI) agonists, tyrosine phosphorylation of signaling molecules, including spleen tyrosine kinase (Syk) and phospholipase $\mathrm{C}-\gamma 2$ (PLCY2), was decreased in $\mathrm{Ax}^{l^{-/-}}$and $\mathrm{Tyro}^{-/-}$platelets, but not in Mertk ${ }^{-1-}$ platelets. While platelet aggregation induced by agonists did not differ in the presence or absence of the Gas6 neutralizing antibody, the platelet aggregation was inhibited by anti-Axl or anti-Tyro3 neutralizing antibodies antibody, but not the anti-Mertk antibody. Additionally, the recombinant extracellular domain of Axl or Tyro3, but not that of Mertk, also inhibited platelet aggregation.

Conclusions: These data suggest that Axl and Tyro3, but not Mertk, have an important role in platelet activation and thrombus formation, and mechanistically may do so by a pathway that regulates inside to outside signaling and heterotypic interactions via the extracellular domains of TAMs.
\end{abstract}

Keywords: Gas6 receptors, Platelet, Activation, Thrombosis, Trans interaction

\section{Backgroud}

Tyro3, Axl, and Mertk comprise the members of the TAM family of receptor tyrosine kinases that participate in a number of important physiological functions that include the clearance of apoptotic cells, resolution of inflammation, as well as platelet aggregation and clot formation. Structurally, TAM receptors share a characteristic domain

\footnotetext{
* Correspondence: zhoujunsong417@163.com; yiwu@temple.edu ${ }^{1}$ Cyrus Tang Hematology Center, Collaborative Innovation Center of Hematology, State Key Laboratory of Radiation Medicine and Protection, Soochow University, Suzhou 215123, China

Full list of author information is available at the end of the article
}

organization comprising two extracellular immunoglobulin -like domains, two fibronectin type III-like domains, and a C-terminal cytoplasmic tyrosine kinase domain [1]. For conventional outside-to-inside signaling, the main endogenous ligands, Gas6 and Protein S, bind to the TAM receptors via its sex hormone-binding globulin-like domain and activate the intracelluar kinase domain [2-8]. Notably, It has been observed that Gas6 binding to TAM receptors have multiple cell intrinsic roles that regulate cell growth [9], cell survival [10-12], apoptosis [13-15], cell proliferation $[10,16,17]$, cell adhesion $[6,18-21]$, and in

(c) The Author(s). 2018 Open Access This article is distributed under the terms of the Creative Commons Attribution 4.0 International License (http://creativecommons.org/licenses/by/4.0/), which permits unrestricted use, distribution, and 
professional phagocytes apoptotic cell clearance (efferocytosis) [22].

Previously, several studies have shown that TAM receptors (and Gas6) also participate in platelet activation and thrombosis [23-27]. However, the conclusions regarding the function of each TAM receptor is not fully understood. For example, Angelillo-Scherrer et al have shown that deficiency of Gas6 and TAM receptors causes platelet dysfunction and protects mice against thrombosis, and that TAM receptors are equally important in platelet activation [23, 24]. In contrast, other studies using antibodies proposed that the TAM receptors play a distinct role in platelet function [28] and are selectively involved in ADP-mediated platelet activation, but other receptors, such as collagen receptors, are not involved [27]. Furthermore, Chen et al. showed that platelets only express Mertk but not Tyro3 and Axl, and the recombinant extracellular domain of Mertk inhibited platelet aggregation induced by collagen [26]. Clearly, the role of TAM receptors in platelet activation still remains inconclusive and issues need to be addressed such as whether Gas6 receptors are required for platelet activation and if Axl, Tyro3, and Mertk play an equal role in platelet activation and thrombosis. It is important to address these issues because it will not only help understand the specific functions of these TAM receptors in platelet activation and thrombosis, but it may also reveal the potential target for anti-thrombosis treatment.

In this study, we tested single TAM-knockout and found that the deficiency of Axl or Tyro3 markedly inhibited platelet aggregation, integrin $\alpha \operatorname{IIb} \beta 3$ activation, granule secretion, platelet spreading, intracellular tyrosine phosphorylation, and platelet thrombus formation in vivo. Correspondingly, blockade of Axl or Tyro3 by specific antibodies and recombinant extracellular domains suppressed platelet activation. In contrast, neither the deficiency of Mertk nor the inhibition of Mertk affected platelet activation. These observations provide evidence that Axl and Tyro3 play an important role in platelet activation and thrombosis, and may serve as a better target than Mertk for inhibition of thrombosis.

\section{Methods and materials}

\section{Mice}

The knockout mice with deficiency of Mertk, Axl and Tyro-3 were generated as previously described [29].

\section{Preparation of washed platelets}

All studies on human platelets were performed after approval by the Institution Review Board. Platelets were prepared as described previously [30, 31]. Briefly, $8.6 \mathrm{~mL}$ of blood was drawn into $1.4 \mathrm{~mL}$ of acid-citrate dextrose (ACD) solution $(65 \mathrm{mM}$ sodium citrate, $70 \mathrm{mM}$ citric acid, and $100 \mathrm{mM}$ dextrose, $\mathrm{pH}$ 4.4). After centrifugation at $250 \mathrm{x} \mathrm{g}$ for $20 \mathrm{~min}$, platelet-rich plasma (PRP) was collected and gel-filtered on a Sepharose 2B column equilibrated in a Tyrode-albumin solution. Mouse blood was drawn by inferior vena cava puncture after anesthesia by pentobarbital $\left(50 \mathrm{mg} \mathrm{kg}^{-1}\right)$ [30]. Blood was collected into ACD and was diluted (1:3) with modified Tyrode's buffer $(137 \mathrm{mM} \mathrm{NaCl}, 20 \mathrm{mM}$ HEPES, $5.6 \mathrm{mM}$ glucose, $1 \mathrm{~g} \mathrm{~L}^{-1} \mathrm{BSA}, 1 \mathrm{mM} \mathrm{MgCl}_{2}, 2.7 \mathrm{mM} \mathrm{KCl}$, and $3.3 \mathrm{mM} \mathrm{NaH}_{2} \mathrm{PO} 4, \mathrm{pH} 7.4$ ). Blood was centrifuged at $230 \mathrm{~g}$ for $10 \mathrm{~min}$, to obtain platelet-rich plasma (PRP). To prepare washed platelets, PEG1 (final concentration, $1 \mu \mathrm{M}$ ) and apyrase (final concentration, $0.2 \mathrm{U} \mathrm{mL}^{-1}$ ) was added to PRP. Washed platelets were prepared by centrifuging PRP at $980 \mathrm{~g}$ for $15 \mathrm{~min}$ and platelet pellets were resuspended in modified Tyrode's buffer.

\section{Platelet aggregation}

Platelet aggregation was monitored by measuring light transmission with the use of an aggregation analyzer (CHRONO-LOG Corporation, 560CA). The instrument was calibrated with a washed platelet suspension $(3 \times$ $10^{8}$ platelets $\mathrm{mL}^{-1}$ ) for zero light transmission and with buffer for $100 \%$ transmission. Aggregation was initiated by addition of agonists under constant stirring at 1200 rpm at $37^{\circ} \mathrm{C} . \mathrm{CaCl}_{2}$ were added at final concentration of $1 \mathrm{mM}$ immediately before platelet stimulation.

\section{Platelet spreading assay}

Coverslips were coated with $10 \mu \mathrm{g} \mathrm{mL}^{-1}$ fibrinogen overnight at $4{ }^{\circ} \mathrm{C}$ and blocked with $1 \%$ fatty acid-free BSA. Washed platelets in Tyrode's buffer supplemented with $1 \mathrm{mM} \mathrm{CaCl}{ }_{2}$ and agonist were seeded on coverslips and incubated at $37^{\circ} \mathrm{C}$ for $30 \mathrm{~min}$. After washing and fixation with $4 \%$ paraformaldehyde, the adherent platelets were stained with TRITC-conjugated phalloidin (F-actin stained, 1:500), containing $0.1 \%$ Triton $\mathrm{X}-100$, for $2 \mathrm{~h}$. The samples were observed under a fluorescence microscope (Olympus FSX100) and photographed. The area of spread of platelets was calculated using NIH Image J software.

\section{Immunoprecipitation and western blotting}

After platelets were activated, reactions were terminated by addition of an equal volume of $2 \mathrm{X}$ ice-cold lysis buffer $(100 \mathrm{mM}$ Tris/HCl pH 7.4, 1\% Triton X-100, $3 \mathrm{mM}$ EGTA) containing $2 \mathrm{X}$ protease inhibitor and $2 \mathrm{X}$ phosphatase inhibitor cocktail. After incubation on ice for 30 min, the samples were centrifuged at $14,800 \mathrm{rpm}$ for 10 min, the supernatant was removed and incubated with the indicated antibodies in rotation at $4{ }^{\circ} \mathrm{C}$ for $2 \mathrm{~h}$, followed by incubation with protein $G$ sepharose beads for $1 \mathrm{~h}$. Protein $\mathrm{G}$ sepharose beads were washed three times with $1 \mathrm{X}$ lysis buffer and SDS reducing buffer was added to the beads. The beads were boiled for $3 \mathrm{~min}$. 
Precipitated proteins or whole cell lysate were separated by 8\% SDS-PAGE and electrophoretically transferred onto a PVDF membrane. Membranes were blocked with 5\% BSA in PBS. After extensive washing with Tris-buffered saline (TBS) containing $0.1 \%$ Tween 20 , the membrane was incubated with antibodies at room temperature for $2 \mathrm{~h}$. Antibody binding was detected using IRDye 800-conjugated goat anti-mouse IgG or IRDye 680-conjugated goat anti-rabbit IgG and visualized with the Odyssey Infrared Imaging System (LI-COR).

\section{Flow cytometric analysis}

Washed platelets or PRP was incubated with antibodies plus PBS (negative control), poly(PHG), or convulxin, CRP, or thrombin for $15 \mathrm{~min}$ without stirring at room temperature, followed by fixation with $1 \%$ paraformaldehyde in PBS [32]. Samples were analyzed by performing flow cytometry using a FACScan instrument and CellQuest software (BD Biosciences).

\section{Murine platelets isolation and analysis of TAM receptor expression}

Wild-type mice (C57BL/6 J strain) were placed under terminal anesthesia using rodent ketamine cocktail and blood was drawn into $0.3 \mathrm{~mL}$ of acid-citrate dextrose (ACD) solution from inferior vena cava. The blood was mixed with 100 mM EGTA containing modified Tyrode's calcium-free buffer (EGTA buffer) and centrifuged at $180 \mathrm{x} \mathrm{g}$ at $22^{\circ} \mathrm{C}$ for $10 \mathrm{~min}$. The platelet-rich plasma was collected and mixed with $0.25 \mu \mathrm{M}$ prostaglandin E1 containing EGTA buffer (washing buffer) and centrifuged at $1250 \mathrm{x} \mathrm{g}$ at $22^{\circ} \mathrm{C}$ for $10 \mathrm{~min}$. The pellet containing mainly platelets was collected and washed twice as above using washing buffer. The platelet pellet was resuspended and counted. TAM receptor expression on the surface was analyzed by flow cytometry using anti-mouse CD41 (133,913 (Biolegend), anti-mouse Tyro3 (FAB759P R\&D), anti-mouse Axl (FAB8541P R\&D), anti-mouse Mertk (12-5751-80 (eBioscience) antibodies.

\section{Intravital microscopy of laser-induced thrombosis of the cremaster muscle arterioles}

Laser-induced injury of the mouse cremaster muscle arteriole was performed as previously described [33-35]. Alexa 488-labeled anti-CD41 F(ab)2 fragments (BD Biosciences) were infused at $0.1 \mu^{g^{-1}}$ into the jugular vein. After $5 \mathrm{~min}$, arterioles (30 to $45 \mu \mathrm{m}$ diameter) were injured using a laser ablation system (Intelligent Imaging Innovations (I3)) using a Zeiss microscope (Axio Examiner D1) parfocal objective as the focal plane. The laser power was set to $55-65 \%$, and the laser fired at the vessel wall in 1 to 3 pulses until thrombi were induced. Approximately 10 thrombi were studied in a single mouse.
Injuries in which puncture of the vessel occurred or injuries in which no thrombus formed were excluded. The average number of laser pulses/injury was equal for all conditions. Data were captured using a CCD camera (Cool SnapTM HQ2) using Slidebook 5.0 image acquisition and analysis software (I3). Data were collected for 5 min after vessel wall injury. Image analysis was performed using Slidebook Version 5.0 (I3). Data were obtained from a total of 30 thrombi per group for each experimental condition. The method for the in vivo experiments was performed as described [33, 36, 37].

\section{Generation of recombinant proteins expressing the extracellular domain of TAM}

The cDNA expressing the soluble form of the extracellular domain of TAM was subcloned into a pEF2-SPFL vector that provided a signal peptide followed by the Flag epitope fused in frame with the TAM extracellular domain. As such, these plasmids have signal sequences that allow the coded protein to be secreted from mammalian cells. Soluble TAM protein (s-TAM) was expressed by mammalian cells and purified from conditioned medium using ANTI-FLAG ${ }^{\oplus}$ M2 Affinity Gel (A2220, Sigma-Aldrich).

\section{Statistical analysis}

Data were analyzed using the statistical software GraphPad Prism 5. For parametric comparison, the values were expressed as the mean \pm SEM, one-way ANOVA (analysis of variance) followed by Tukey's multiple comparison test or Dunnett's multiple comparison test. The two-tailed Student's t-test for 2 groups was used. The statistics for the in vivo experiments were performed as described [37, 38]. For the non-parametric comparison between multiple groups the area under the curve (AUC) of median FI over $300 \mathrm{~s}$ was analyzed with a one-way ANOVA, followed by the Kruskal-Wallis test $[37,38]$. A $P$ value less than 0.05 was considered significant.

\section{Results}

Impaired aggregation of platelets in $\mathrm{Tyro3}^{-/-}$or $\mathrm{Axl}^{-/-}$, but not in Mertk ${ }^{-/-}$platelets in response to GPVI agonist stimulation

The contribution(s) of individual TAM receptors in platelet activation remains incompletely understood [23-28]. To investigate the contribution of each receptor individually, we first purified murine platelets from C57BL/6 J strain, and analyzed TAM receptor expression on the surface of platelets by flow cytometry (Fig. 1a). As indicated, murine platelets express all three TAM receptors at similar expression levels. However, despite overlapping expression, it is not clear whether they have 


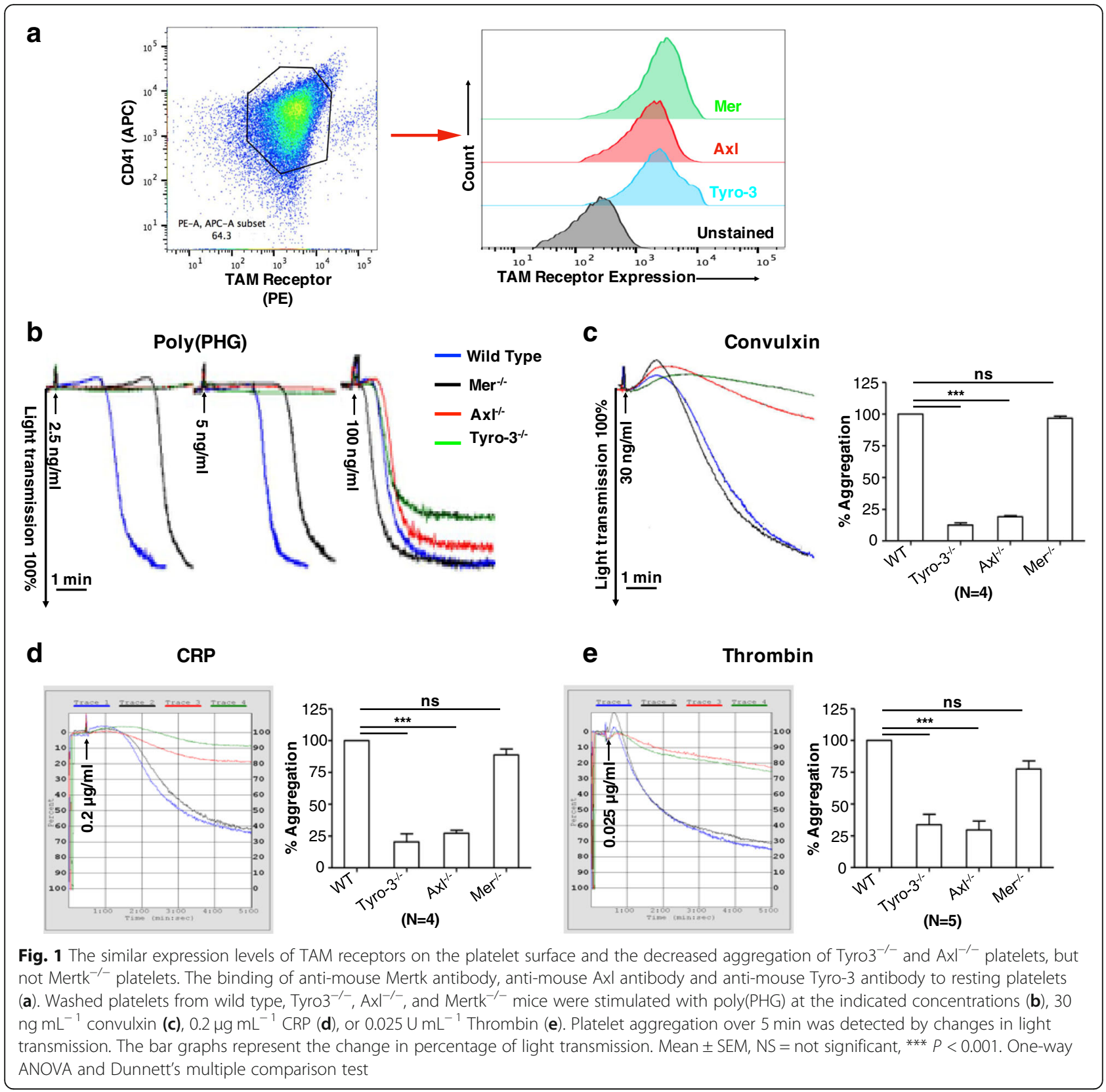

unique or distinct functions in platelet biology and thrombosis.

To address this query, we examined single TAM receptor knockout mice individually, focusing on platelet activation mediated by three specific glycoprotein VI (GPVI) receptor agonists to compare functional outcomes in a side-by-side manner. GPVI agonists used in study are (i) poly(PHG), (ii) CRP, and (iii) convulxin. Poly(PHG) is a synthetic collagen fiber peptide for specific activation of GPVI (29), whereas CRP, Collagen-related triple helical peptide, platelet GPVI ligand [39-43]. Convulxin is a snake venom lectin that specifically activates GPVI $[44,45]$. When stimulated with poly(PHG) at 2.5 and $5 \mathrm{ng} \mathrm{mL}^{-1}$, wild-type platelets underwent full aggregation, however, platelets from $\mathrm{Axl}^{-/-}$or $\mathrm{Tyro}^{-/-}$mice failed to aggregate. In contrast, Mertk $^{-/-}$platelets formed aggregates to the same extent as wild-type platelets but at a slower rate (Fig. 1b). The defect in the aggregation of $\mathrm{Axl}^{-/-}$or $\mathrm{Tyro}^{-1-}$ platelets was compromised when stimulated with high concentrations of poly(PHG), $100 \mathrm{ng} \mathrm{mL}^{-1}$, suggesting that their phenotype results from the functional abnormality. Similarly, $\mathrm{Axl}^{-/-}$or $\mathrm{Tyro}^{-/-}$platelets did not aggregate well in response to $30 \mathrm{ng} \mathrm{mL}^{-1}$ convulxin (Fig. 1c) or CRP at $0.2 \mu \mathrm{g} \mathrm{mL}^{-1}$ (Fig. 1d), although Mertk ${ }^{-/-}$platelets aggregated at the same level as wild-type platelets. Platelet 
aggregation was restored when stimulated with a high concentration of CRP (Additional file 1: Figure S1A). Moreover, when the protease-activated receptors PAR4 were stimulated with the agonist thrombin at $0.025 \mathrm{U}$ $\mathrm{mL}^{-1}, \mathrm{Axl}^{-/-}$and $\mathrm{Tyro3}^{-/-}$platelets also did not aggregate well, but $\mathrm{Mertk}^{-/-}$platelets aggregated similar to the wild-type platelets (Fig. 1e). The defect in $\mathrm{Axl}^{-/-}$and $\mathrm{Tyro}^{-/-}$platelet aggregation was overcome when stimulated with a high concentration of thrombin $(0.06 \mathrm{U}$ $\mathrm{mL}^{-1}$, Additional file 1: Figure S1B). Taken together, despite that all three TAMs are uniformly expressed on murine platelets, our results indicate they have distinct effect on platelets, whereby Axl and Tyro3 are critical for platelet aggregation from the above-mentioned platelet agonists that induce inside-to-outside signaling.

\section{Deficiency of Axl and Tyro3 receptor but not Mertk receptor inhibit integrin allb $\beta 3$ activation}

The suppressed platelet aggregation resulting from a deficiency of Tyro3 and Axl receptors suggests that these receptors may also affect the activation of the integrin $\alpha \operatorname{IIb} \beta 3$. To test this hypothesis, washed platelets were stimulated with $0.4 \mu \mathrm{g} \mathrm{mL}^{-1}$ CRP (Fig. 2a) or $0.015 \mathrm{U}$ $\mathrm{mL}^{-1}$ thrombin (Fig. 2b) and activation of the $\alpha \operatorname{IIb} \beta 3$ was assessed by binding of PE-labeled JON/A, which specifically recognizes activated mouse integrin $\alpha \operatorname{IIb} \beta 3$. Similar to the platelet aggregation shown in Fig. 1, JON/ A binding on wild-type and $\mathrm{Mertk}^{-/-}$platelets was largely increased, but not on $\mathrm{Axl}^{-/-}$or $\mathrm{Tyro3}^{-/-}$platelets. When platelet-rich plasma (PRP) was stimulated with $50 \mathrm{ng} \mathrm{mL}^{-1}$ poly(PHG), JON/A binding to platelets was similar among wild-type and TAM-knockout platelets (Additional file 1: Figure S2 Ai), while stimulation with the higher concentration of poly(PHG), $1 \mu \mathrm{g} \mathrm{mL}-1$, binding of JON/A to the platelets was observed similar to the CRP and thrombin (Additional file 1: Figure S2 Aii-Aiii). Without activation, JON/A binding on wild-type, $\mathrm{Mertk}^{-/-}, \mathrm{Axl}^{-/-}$, and $\mathrm{Tyro3}^{-/-}$platelets were similar (Additional file 1: Figure $\mathrm{S} 2 \mathrm{Bi}$ ). In addition, stimulation with $3.5 \mu \mathrm{g} \mathrm{mL}^{-1}$ convulxin (Additional file 1: Figure S2 Bii- Biii), significantly increased JON/A binding on wild-type and $\mathrm{Mertk}^{-/-}$platelets, but not on

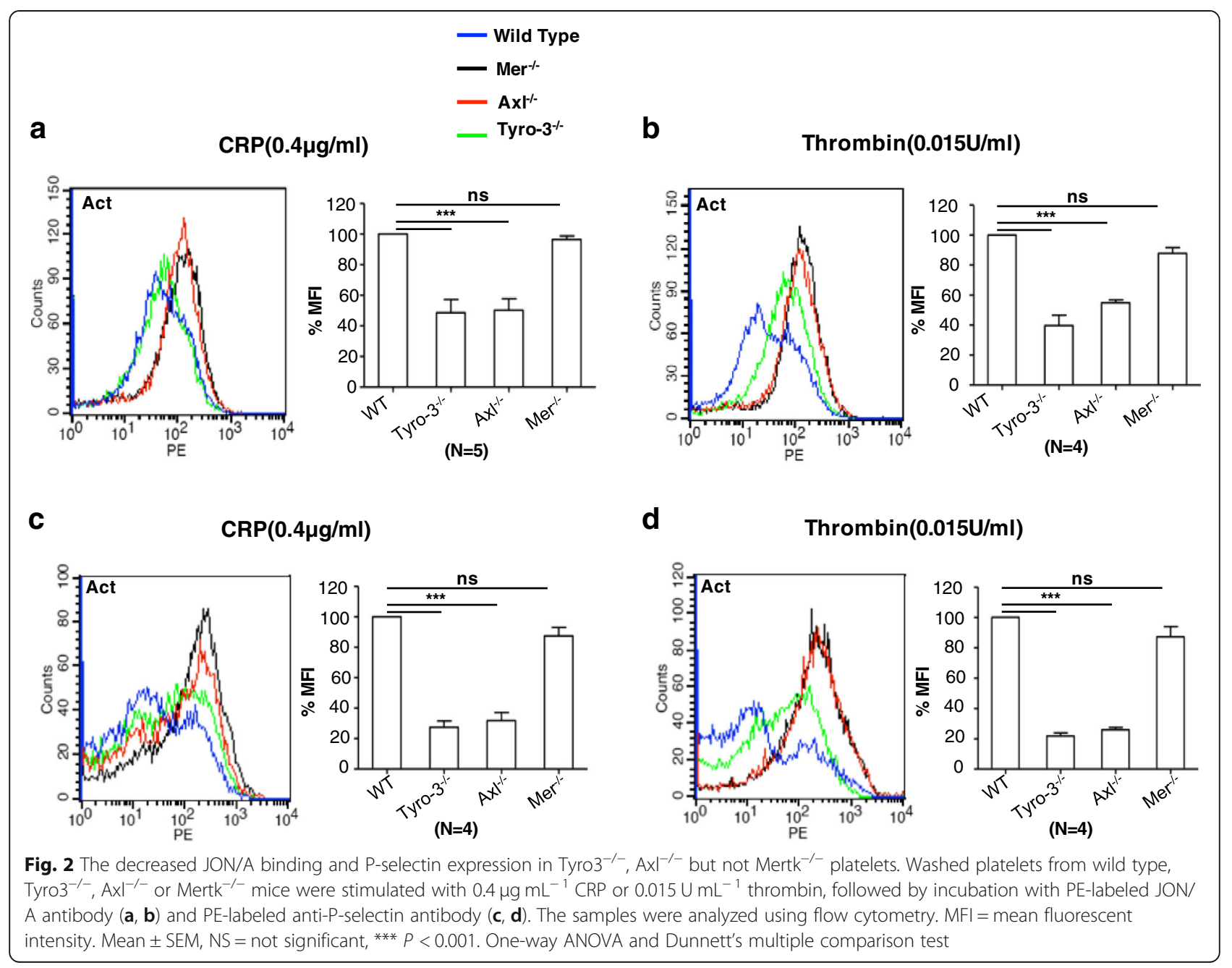


$\mathrm{Axl}^{-1-}$ or $\mathrm{Tyro}^{-1-}$ platelets was observed. Analogous to the results described above, these data suggest that Axl and Tyro3 receptor are required for integrin $\alpha \operatorname{IIb} \beta 3$ activation.

\section{Secretion of a-granule is impaired in $\mathrm{Tyro3}^{-/-}$and $\mathrm{Axl}^{-/-}$ platelets}

Aggregation-dependent platelet $\alpha$-granule secretion is essential for the formation of stable macroaggregates after initial formation of small and reversible platelet aggregates. To test whether TAM receptors are involved in platelet secretion, we measured the membrane expression of P-selectin, a marker of platelet $\alpha$-granule release, by flow cytometry. Washed platelets were stimulated either with $0.4 \mu \mathrm{g} \mathrm{mL}^{-1} \mathrm{CRP}$ (Fig. 2c) or $0.015 \mathrm{U} \mathrm{mL}^{-1}$ thrombin (Fig. 2d) and P-selectin expression was analyzed. The P-selectin expression was higher on wild-type or $\mathrm{Mertk}^{-1-}$ platelets, but not on $\mathrm{Axl}^{-1-}$ or $\mathrm{Tyro}^{-1-}$ platelets. When using the PRP and stimulating platelets with $0.5 \mu \mathrm{g} \mathrm{mL}^{-1}$ poly(PHG), increased expression was P-selectin expression was observed on wild-type and TAM knockout platelets (Additional file 1: Figure S3 Ai). Stimulation at higher concentration of poly(PHG), $2 \mu \mathrm{g} \mathrm{mL}^{-1}$ (Additional file 1: Figure S3 Aii-Aiii), or $2.5 \mu \mathrm{g} \mathrm{mL}^{-1}$ convulxin (Additional file 1: Figure S3 Bi) increased P-selectin expression on wild-type and Mertk $^{-/-}$platelets, but not on $\mathrm{Axl}^{-/-}$or $\mathrm{Tyro3}^{-/-}$platelets was observed. Without activation with agonists, P-selectin expression on wild-type, $\mathrm{Mertk}^{-/-}, \mathrm{Axl}^{-/-}$, and $\mathrm{Tyro}^{-/-}$platelets was similar. These findings suggest that Axl and Tyro-3, but not Mertk, plays a role in the $\alpha$-granule secretion.

\section{Deficiency of Tyro3 and Axl, but not Mertk, inhibit platelet spreading}

We further investigated role of TAM receptors on the platelet activation by analyzing platelet spreading. Mouse platelets were incubated on fibrinogen-coated coverslips and stimulated with $5 \mathrm{ng} \mathrm{mL}^{-1}$ poly(PHG). Five $\mathrm{ng} \mathrm{mL}^{-}$ ${ }^{1}$ poly(PHG) significantly stimulated lamellipodia formation in the wild-type and $\mathrm{Mertk}^{-1-}$ platelets, but not in $\mathrm{Tyro3}^{-/-}$and $\mathrm{Axl}^{-/-}$platelets (Fig. 3a). In the presence of poly(PHG), the area of wild-type platelets undergoing spreading was $20.523 \pm 2.641 \mu \mathrm{m}^{2}$, which was significantly larger than that of $\mathrm{Tyro}^{-/-}$platelets $(6.016 \pm$ $\left.0.513 \mu \mathrm{m}^{2}\right)$ and $\mathrm{Axl}^{-/-}$platelets $\left(8.573 \pm 1.012 \mu \mathrm{m}^{2}\right)$, but it was similar to that of Mertk $^{-/-}$platelets $(15.707 \pm$ $1.673 \mu \mathrm{m}^{2}$ ) (Fig. 3aii). We further examined whether the defect in platelet activation resulted from the down-regulation of membrane receptors or integrin $\alpha I I b \beta 3$ levels in the absence of TAM receptors by analyzing the surface expression of GPVI, GPIb, and integrin $\alpha \operatorname{IIb} \beta 3$ on the platelets, however their expression levels were comparable among wild-type and the TAM single knockout platelets (Fig. 3b-d). Thus, the loss of TAM receptors does not affect the expression of functional glycoproteins on the platelet membrane but ablation of Axl and Tyro3 receptors significantly affects the platelet spreading.

\section{AxI and Tyro-3, but not Mertk are required for platelet accumulation}

To confirm whether the role of TAM receptors in platelet activation in vitro is consistent with that of platelet accumulation in vivo, we have used a laser-induced injury model as described previously [33, 36, 37]. Thrombosis was analyzed with fluorescence intravital microscopy. Following laser-induced cremaster arteriolar wall injury, platelet accumulation was visualized by infusion of Alexa Fluor 488-conjugated anti-CD41 Fab fragments. The role of TAM receptor in the platelet accumulation was examined using wild-type, Mertk $^{-/-}$, $\mathrm{Axl}^{-1-}$, and $\mathrm{Tyro3}^{-/-}$mice. The median integrated fluorescence intensity obtained from quantitative data from multiple thrombi indicated that $\mathrm{Axl}^{-/-}$and $\mathrm{Tyro}^{-/-}$, but not Mertk $^{-/}$mice have defects in platelet accumulation at the sites of injury as compared to control, wild-type mice (Fig. 4a,b). These data suggests that Axl and Tyro-3, but not Mertk receptor is required for platelet accumulation in vivo.

\section{Stimulated protein tyrosine phosphorylation is suppressed in platelets lacking the Tyro3 or Axl receptor} The results above suggest that Tyro3 and Axl receptors participate in platelet activation and thrombosis. Therefore, to further test whether intracellular signaling during platelet activation is regulated by TAM receptors, we investigated the GPVI signaling pathway. As shown in Fig. 5a, convulxin stimulates tyrosine phosphorylation of a series of proteins in wild-type platelets in a time-dependent manner. Interestingly, tyrosine phosphorylation of proteins with molecular weights between 70 and $150 \mathrm{kDa}$ was attenuated in $\mathrm{Tyro}^{-/-}$platelets. It is well known that GPVI elicits a signal transduction cascade that involves sequential activation of Syk, LAT, and SLP-76, leading to PLC $\gamma 2$ activation [41, 46-51]. To determine whether the deficiency of Tyro3 inhibits this pathway, PLC 2 was immunoprecipitated and its tyrosine phosphorylation was evaluated. The tyrosine phosphorylation of PLC 22 was strongly induced in wild-type platelets stimulated with convulxin, while it was completely suppressed in $\mathrm{Tyro}^{-1-}$ platelets. Similar phosphorylation of PLCY2 was also obtained for $\mathrm{Axl}^{-/-}$, but not for Mertk $^{-/-}$platelets (data not shown). In order to further understand the regulation of TAM receptors on the upstream signaling molecule PLCY2, we collected wild-type and TAM single knockout platelets stimulated with convulxin at two time points, zero and two 


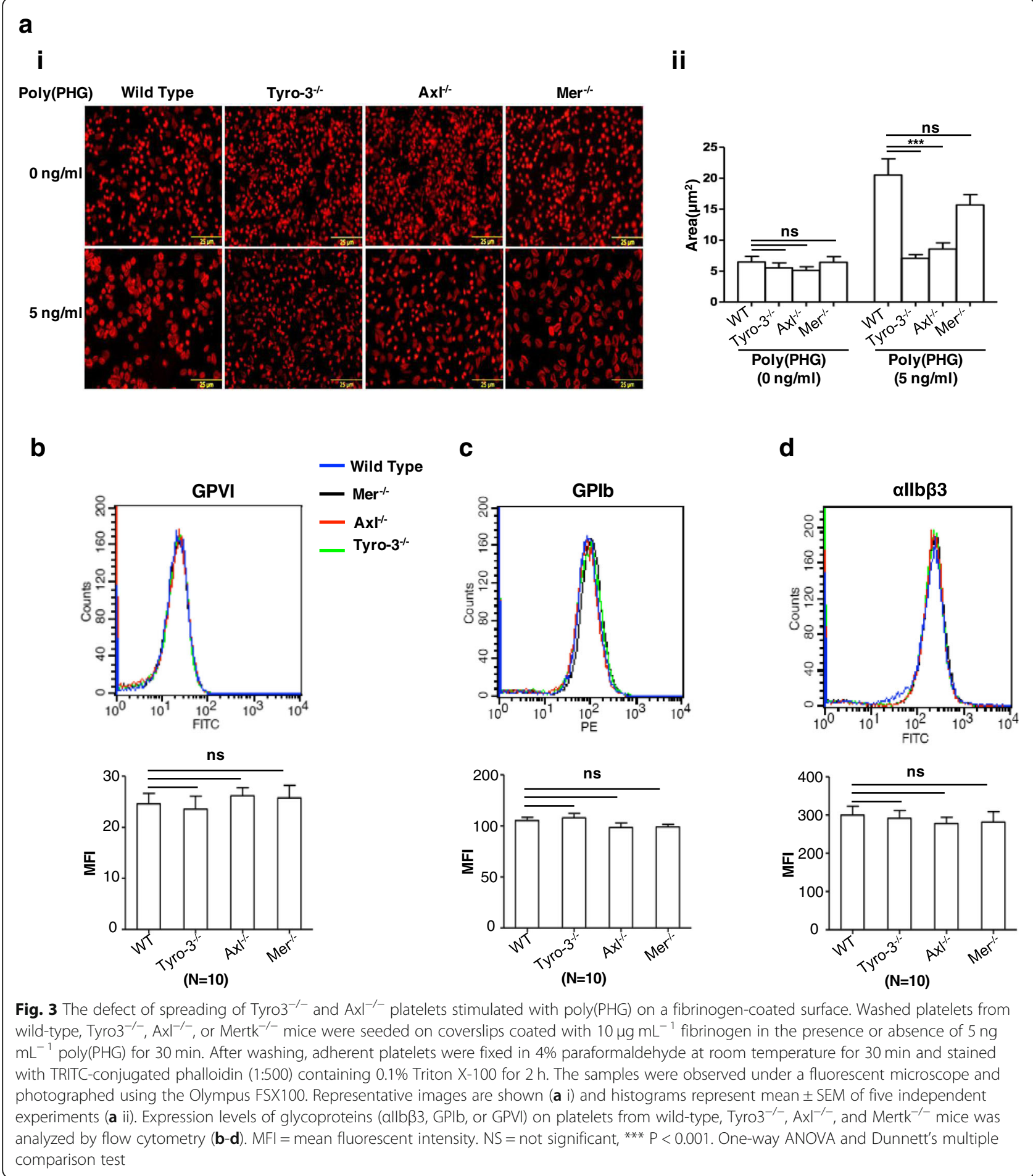

minutes, and determined tyrosine phosphorylation of Syk using immunoprecipitation. As shown in Fig. 5c, tyrosine phosphorylation of Syk was strongly suppressed in $\mathrm{Tyro3}^{-/-}$and $\mathrm{Axl}^{-/-}$platelets, but not in $\mathrm{Mertk}^{-/-}$ platelets. The above findings imply that the Tyro3 and Axl receptors are important for the inside-to-outside signaling involving PLC $\gamma 2$ and GPVI signaling.
Trans-interaction of Axl or Tyro3 may mediate contactdependent activation

The above-mentioned results indicate that Tyro3 and Axl, but not Mertk, participate in an inside-out GPVI to TAM signaling mechanism in platelets, leading to collagen -mediated platelet aggregation and subsequently thrombus formation. In other cell types, TAM receptors 

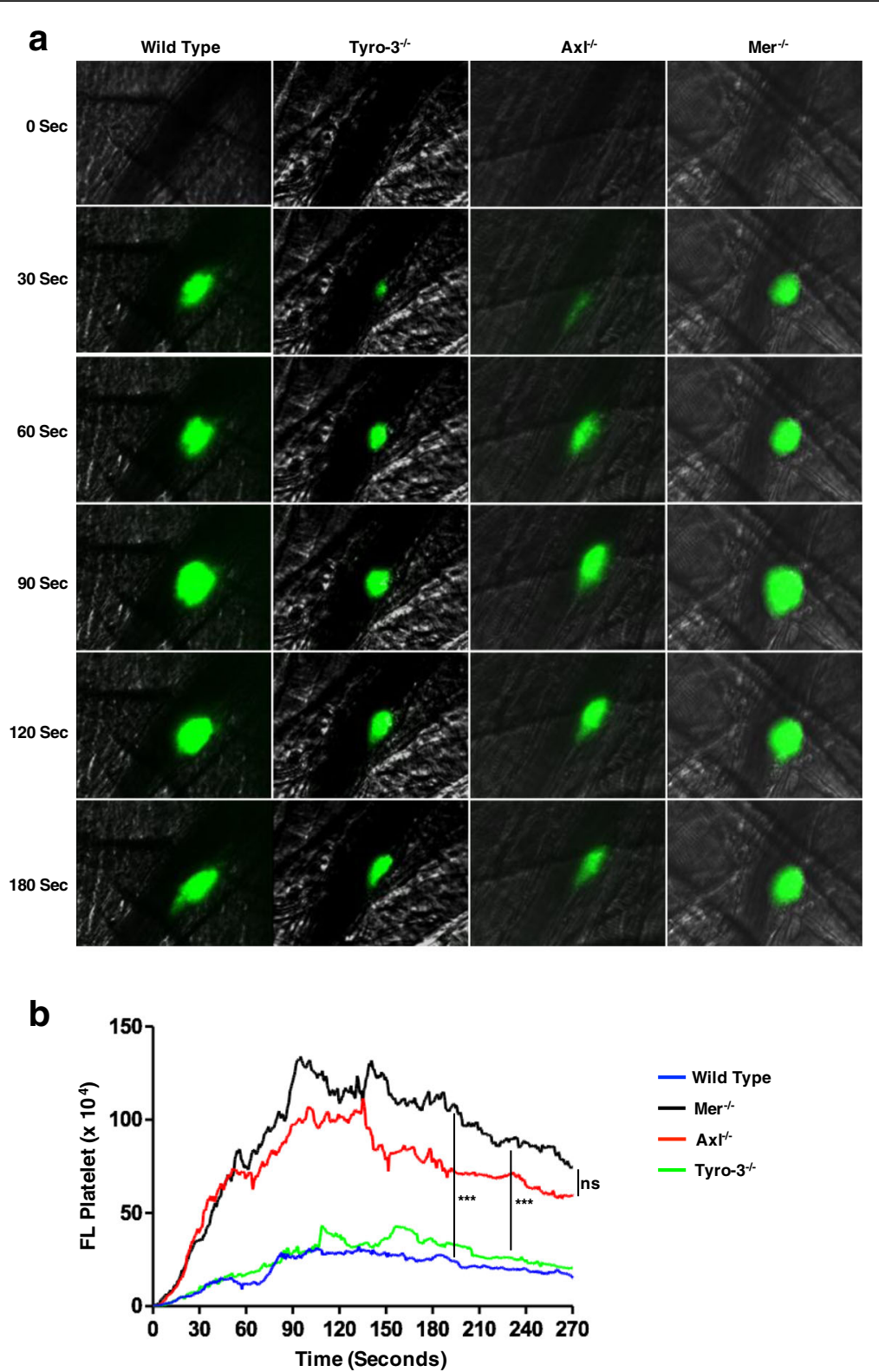

Fig. 4 Tyro3 and Axl, but not Mertk, are required for platelet accumulation in vivo. Cremaster arteriole injury was induced in Tyro $3^{-/-}, \mathrm{AxI}^{-/-}$, Mertk $^{-1-}$, and wild-type mice. Platelets were detected using anti-CD41 F(ab)2 fragments (binding to platelet allb) conjugated with Alexa Fluor 488. (a) Using intravital microscopy, representative fluorescence images show platelet accumulation (green) at selected time points up to $180 \mathrm{~s}$ after vascular injury. The median integrated fluorescence intensities (FI) of anti-CD41 antibody over $270 \mathrm{~s}$ (platelet, $\mathbf{b}$ ). The data were analyzed by the area under the curve (AUC) with one-way ANOVA and Kruskal-Wallis test. The data were obtained from 30 thrombi in 3 mice for each experimental condition. $\mathrm{NS}=$ not significant, ${ }^{* * *} \mathrm{P}<0.001$

have been shown to mediate ligand-independent cell-cell contact formation via homophilic interactions of extracellular domains [52, 53]. Hence, to further investigate whether TAMs also participate in outside-in signaling and/or heterotypic trans-interactions that depend on their extracellular domains, we tested a series of extracellular blocking agents that included (i) anti-Gas6 neutralizing antibody (Fig. 6a-d) (ii) anti-TAM neutralizing mAbs (Fig. 6e) and (iii) TAM ectodomain soluble receptor traps (Fig. 6f), to investigate whether autocrine-inside to outside signaling also contributes in this model.

To analyze autocrine-inside to outside signaling, we pre-treated murine platelets with either IgG control or Gas6 Ab $(20 \mu \mathrm{g} / \mathrm{ml})$ following stimulation with several GPVI agonists, poly(PHG) $(10 \mathrm{ng} / \mathrm{ml})$ (Fig. 6a), convulxin $(30 \mathrm{ng} / \mathrm{ml})$ (Fig. 6b), CRP $(0.1 \mu \mathrm{g} / \mathrm{ml})$ (Fig. 6c), or thrombin $(0.015 \mathrm{U} / \mathrm{ml})$ (Fig. 6d). As noted, under these 


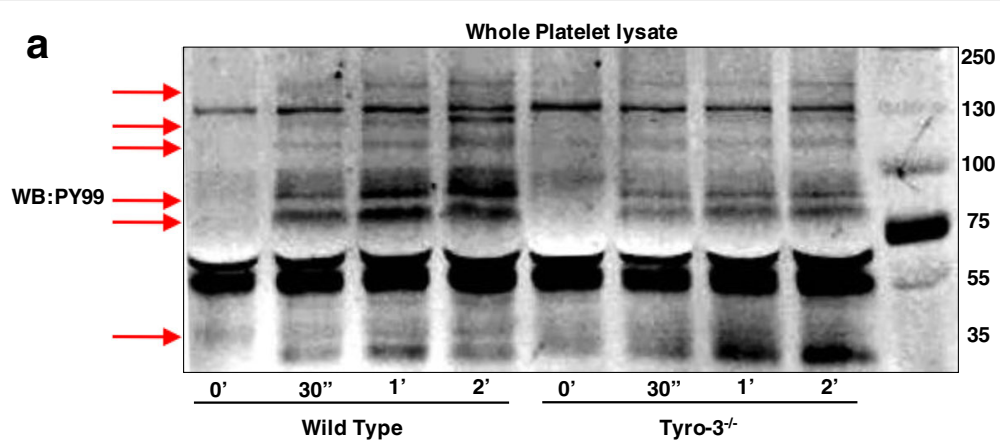

b

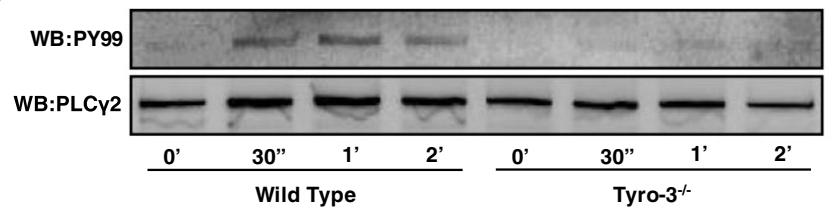

C

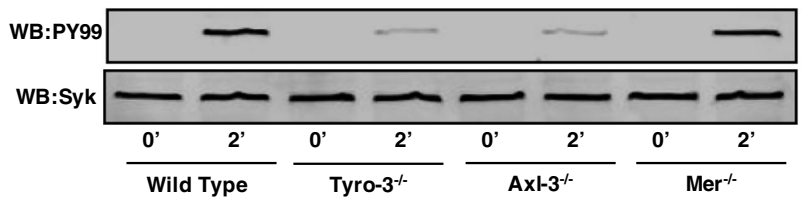

Fig. 5 GPVI-stimulated protein tyrosine phosphorylation is inhibited in the absence of Tyro3 and Axl, but not Mertk. After wild-type and Tyro3 ${ }^{-/-}$ platelets were stimulated with $30 \mathrm{ng} \mathrm{mL}^{-1}$ convulxin for the indicated time period, platelets were solubilized and the lysates were subjected to immunoprecipitation with antibody against PLC 2 2. Whole cell lysates (a) or anti-PLCY2 immunoprecipitates (b) were analyzed for tyrosine phosphorylation by immunoblotting using PY99. Equal protein loading was assured by probing the samples with antibody against PLCY2. (c) Tyro $^{-1-}, \mathrm{Axl}^{-1-}$, Mertk $^{-1-}$, and wild-type platelets were stimulated with $30 \mathrm{ng} \mathrm{mL}^{-1}$ convulxin for $2 \mathrm{~min}$, platelets were solubilized and the lysates were subjected to immunoprecipitation with antibody against Syk. The anti-Syk immunoprecipitates were analyzed for tyrosine phosphorylation using PY99. The blots are representative of three independent experiments

conditions, we failed to see blockage of platelet aggregation under these conditions. The results suggest that autocrine stimulation of TAMs, via locally autocrine produced Gas6 may not be responsible for the observed inside-to-outside GPVI mediated TAM-dependent platelet activation. To more formally test this idea, we treated platelets with either anti-TAM mAbs to the extracellular domains (Fig. 6e) or ectodomain soluble traps for TAM receptor (Fig. 6f) following stimulation with convulxin $(30 \mathrm{ng} / \mathrm{ml})$. The pre-incubation with an anti-Tyro3 or an anti-Axl antibody strongly inhibited convulxin induced platelet aggregation. However no effect of anti-Mertk antibody was observed on the platelet aggregation (Fig. 6e). Notably, these antibodies recognize the extracellular portion of the receptors. Additionally, pretreatment with soluble recombinant proteins against extracellular domains of Axl and Tyro3, but not that of Mertk, inhibited convulxin-stimulated platelet aggregation (Fig. 6f). Taken together, these data suggest that trans-interaction of Axl or Tyro3 can mediate contact-dependent activation, facilitating the activation of signaling and integrin $\alpha \operatorname{IIb} \beta 3$ activation leading to the platelet activation and aggregation (Fig. 7).

\section{Discussion}

Formation of early thrombi after vascular injury begins with the local exposure of collagen and generation of thrombin, followed by the tethering of circulating platelets by collagen and the subsequent accumulation of aggregated platelets. Once activated, platelets form persistent contact with each other, allowing molecules on the surface of adjacent platelets to interact in trans and facilitate thrombus growth and stability. Thus, understanding the spectrum of molecules involved and their activation mechanisms are important. This information is expected to reveal the processes of initial thrombus formation and help in identifying novel targets for anti-thrombotic therapy.

Previously, in other cell types, the trans-interaction of TAM receptors is one example of contact-dependent signaling [52, 53]. In this study, we provided evidence that the TAM receptors Axl and Tyro3 have an important function in platelet activation and thrombosis, including aggregation, integrin $\alpha \operatorname{IIb} \beta 3$ activation, $\alpha$-granule release, platelet spreading, and platelet accumulation in vivo (Fig. 1-3). In contrast, Mertk appears to be dispensable for platelet activation under the conditions used in this study. Contrary to previous studies 


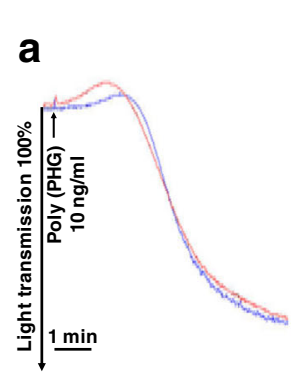

\section{- $\operatorname{lgG}(20 \mu \mathrm{g} / \mathrm{ml})$}

— Gas6 Ab $(20 \mu \mathrm{g} / \mathrm{ml})$

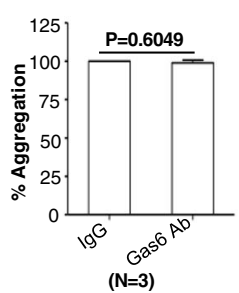

C
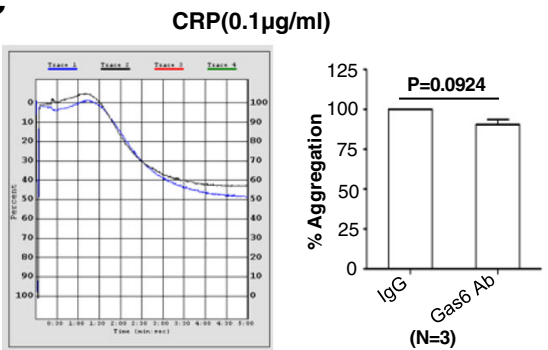

b
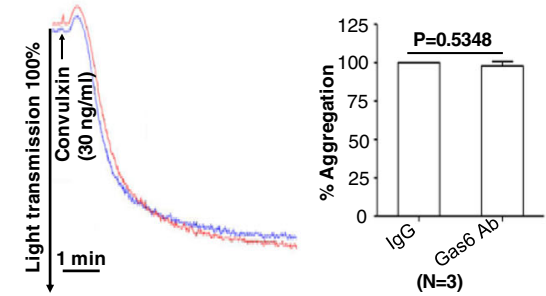

d

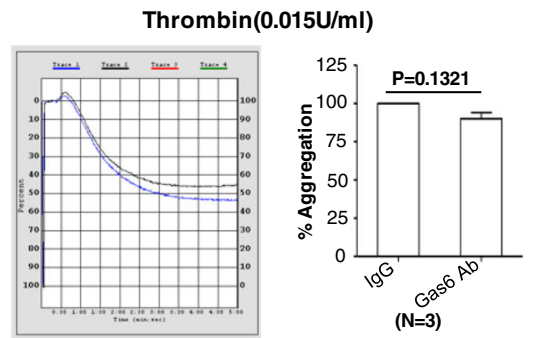

e
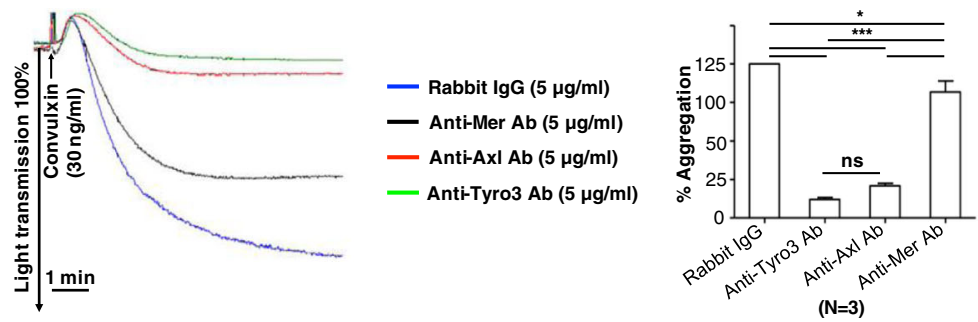

f
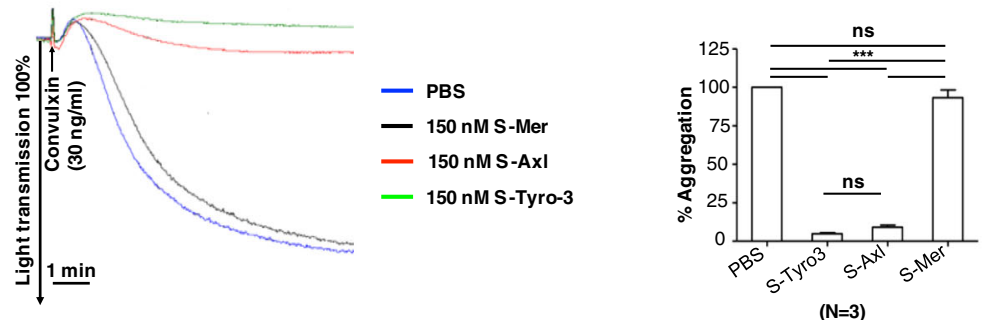

Fig. 6 The trans-interaction of $\mathrm{Axl}$ or Tyro3, but not receptor ligation is not involved in platelet activation. After incubation with $20 \mu \mathrm{mg} \mathrm{L}^{-1}$ anti-Gas6 antibody or isotype control lgG for $5 \mathrm{~min}$, human platelets at a density of $2 \times 10^{8} \mathrm{~mL}^{-1}$ were stimulated with $10 \mathrm{ng} \mathrm{mL}^{-1}$ poly(PHG) (a), $30 \mathrm{ng} \mathrm{mL}^{-1}$ convulxin (b), $0.1 \mathrm{\mu g} \mathrm{mL}^{-1} \mathrm{CRP}(\mathbf{c})$, or $0.015 \mathrm{U} \mathrm{mL}^{-1}$ thrombin (d) to induce aggregation. Mean \pm SEM, NS $=$ not significant. $n=3$, Student's t-test. After human platelets were preincubated with $5 \mu \mathrm{g} \mathrm{mL}{ }^{-1}$ control lgG, anti-Tyro3 Ab, anti-AxI Ab, and anti-Mertk Ab, respectively for $5 \mathrm{~min}$, they were stimulated with $30 \mathrm{ng} \mathrm{mL}^{-1}$ convulxin to induce aggregation(e). After preincubation with $150 \mathrm{nM}$ recombinant extracellular

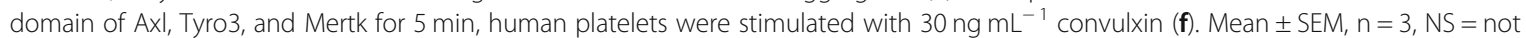
significant, ${ }^{*} P<0.05,{ }^{* *} P<0.001$. One-way ANOVA and Tukey's multiple comparison test

showing that TAM receptors are equally important in platelet activation mediated by physiologic agonists such as ADP and thrombin [24], our results demonstrate that platelet activation and thrombosis mainly rely on Axl and Tyro3. Loss of Axl or Tyro3 expression causes a defect in platelet activation and thrombosis, demonstrating that Axl and Tyro3 have unique roles in signaling pathway required for platelet activation (Fig. 4).
Currently, the mechanisms by which Tyro3 and Axl participate in GPVI and thrombin-mediated PAR signaling is not completely understood, although this likely depends on inside to outside signaling mechanism and trans-activation of the extracellular domains. Whether this requires extracellular Gas6, or Gas6 pre-bound to Tyro3 or Axl (or Pros1 bound to Tyro3) is not resolved in this study, although we did not see an inhibitory effect on platelet aggregation using 


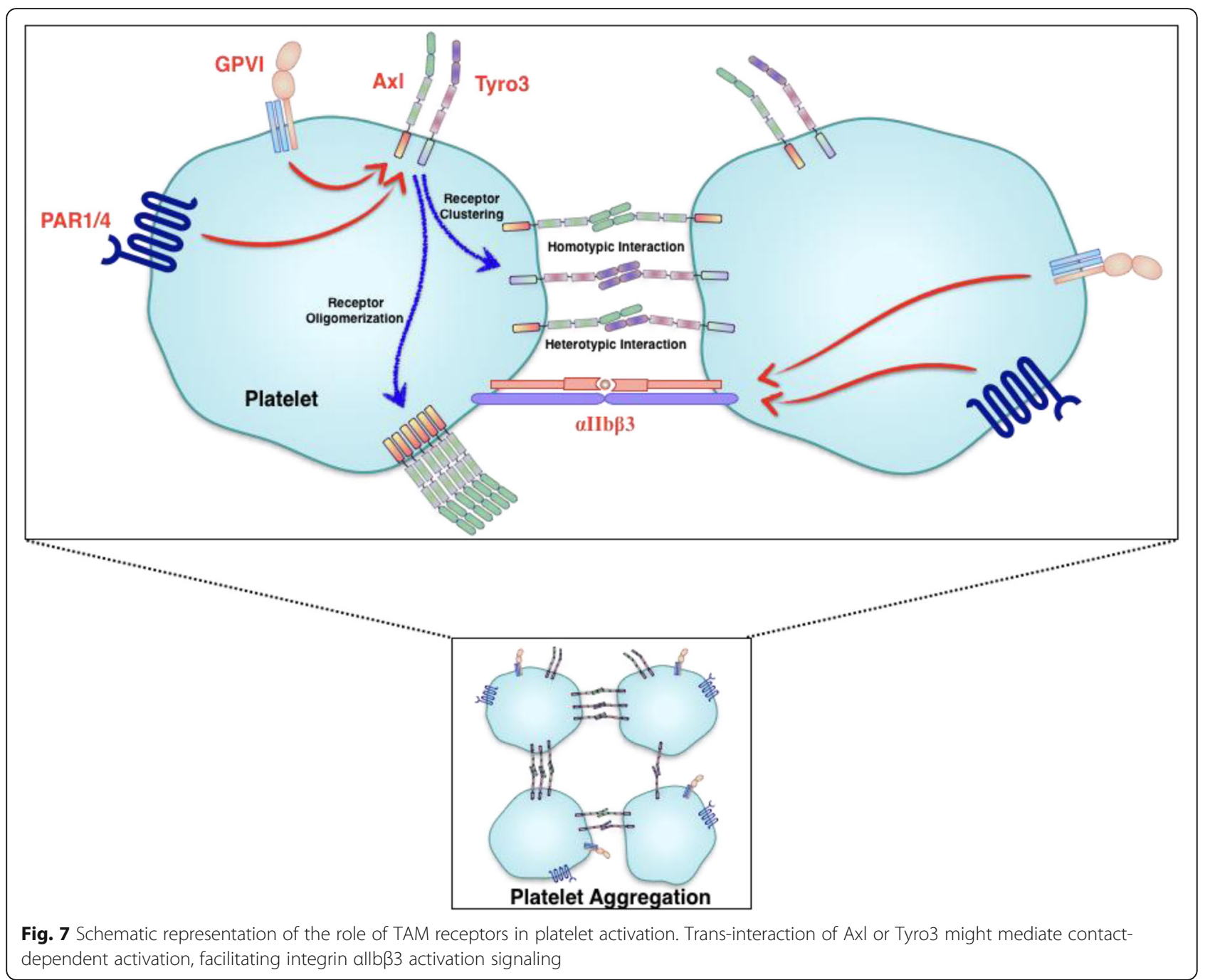

anti-Gas6 antibody that binds to the receptor-binding region. A previous study has shown that plasma Gas6 levels do not influence platelet aggregation [54], so it is conceivable that the Axl/Tyro3-mediated effects for platelet activation and thrombosis are ligand- independent. It is known for example, that in other cell types, TAM receptors may function as cell adhesion receptors in a ligand-independent manner $[52,53,55]$. Indeed, the tandem Ig/FN type III domain structure of TAM extracellular domains are arranged similarly to cell adhesion molecules, such as intercellular adhesion molecules and vascular cell adhesion molecules [56-58]. Moreover, at the molecular level, the Ig domains of Tyro3 form dimers in vitro, both in the crystal and in solution [53], and when Tyro3 is overexpressed either at the cell surface or in the cytoplasm, it can form dimers even in the absence of its ligand [55]. A similar mode of action for Axl was also proposed [52].

Accordingly, in the aforementioned model, in order to allow cell adhesion to occur, TAM receptors displayed on the surfaces of opposing cells may form dimers through homophilic interactions. Although the contribution of a single homophilic interaction might be expected to be weak, a large cluster of dimerized receptors would be sufficient to promote stable platelet-platelet contact at the initial step of receptor stimulation and is probably a prerequisite for full platelet activation. As noted above, this model has been presented for a number of cell adhesion molecules of the Ig superfamily [57, 58] (Fig. 7). The fact that the anti-Tyro3 antibody and the anti-Axl antibody strongly inhibit platelet aggregation (Fig. 6e), as well as their soluble ectodomains (Fig. 6f) that competitively binds to their counterpart receptors in order to inhibit aggregation support the idea that trans-interaction of Axl and Tyro3 is important for platelet activation. We envision that during the initial response to collagen, platelets may utilize Axl and Tyro3 to form stable and close contact with each other, thereby amplifying stimulation of receptors on platelets such as GPVI and PAR1/4. Since both Axl-deficient and Tyro3-deficient platelets have a defective phenotype, Axl 
and Tyro3 may constitute a unique amplification system in normal platelet function and their roles are not redundant.

In addition to the homotypic or heterotyopic interactions within the extracellular domains of Tyro3 and Axl that may mediate aggregation, it is also possible that GPVI and/or PAR receptors induce inside to outside signaling in order to cluster Tyro3 or Axl into higher order aggregates. For example, we have previously shown that Tyro3 (and Mertk) can become hyper-activated in the presence of phosphatidylserine liposomes or apoptotic cells/vesicles, a signaling event predicted to be mediated by receptor clustering $[59,60]$. Additional studies, using mutagenesis in the Ig and FN type III domains, or cryo-EM could be used to better address queries about trans-interactions and receptor clustering. Likewise. it will also be equally important to understand the cause for Mertk being apparently less important in platelet activation and thrombosis, given that Mertk is also sufficiently expressed on platelets. Whether Mertk plays more of a role in outside to inside signaling in platelets, or other signaling role, should be further investigated. Future studies addressing these issues will help in the understanding of the mechanism of platelet activation and thrombosis.

In this study, we provide evidence showing that trans-interaction of Axl or Tyro3 mediate contact-dependent activation, thereby facilitating the activation of platelets and thrombosis. The present results lead to a revised concept for the role of TAM receptors in platelet activation and thrombosis positing that Axl or Tyro3 mediate trans-interaction and contact-dependent activation, thereby facilitating activation of signaling, $\alpha$-granule release, and integrin $\alpha \operatorname{IIb} \beta 3$ activation during aggregation. Identification of the specific functions of Axl and Tyro3 should reveal their potential as therapeutic targets for anti-thrombotic treatment.

\section{Conclusions}

Axl and Tyro-3, but not Mertk, are required to support platelet activation and aggregation. Tyro3 and Axl, but not Mertk receptor is required for thrombus thrombosis. Axl and Tyro-3 mediate the phosphorylation of Syk for platelet function. TAM receptors regulate platelet activation independently of ligand binding. Trans-interaction of Axl or Tyro3 might mediate contact-dependent activation, thereby facilitating the activation signaling and integrin $\alpha \operatorname{IIb} \beta 3$ activation.

\section{Additional file}

Additional file 1: Figure S1. The defect in aggregation of TAM single knockout platelets were compromised when stimulated by high concentration of agonists. (A) CRP(0.6mg $\mathrm{mL}-1)$-induced aggregation $(n=4)$ and $(B)$ Thrombin $(0.06 \mathrm{U} \mathrm{mL}-1)$-induced aggregation $(n=4)$; mean \pm SEM, NS = not significant. One-way ANOVA followed by dunnett's multiple comparison test. Figure S2. JON/A binding is decreased on Tyro3-/and $\mathrm{Axl}-$-/platelets on in response to poly (PHG) and convulxin. Platelets from wild type, Tyro3-/-, Axl-/-or Mer-/-mice were stimulated with poly(PHG) (Ai-Aiii) and convulxin(Bi-Biii), followed by incubation with PElabeled JON/A antibody. The samples were analyzed by flow cytometry. Mean \pm SEM, $n=3, N S=$ not significant, ${ }^{* * *} P<0.001$. One-way ANOVA followed by dunnett's multiple comparison test. Figure S3. The deficiency of Tyro3 and Axl inhibits P-selectin expression on platelet surface in response to poly (PHG) and convulxin. Platelets from wild type, Tyro3-/-, Axl-/- or Mer-/- mice were stimulated with poly(PHG) (Ai-Aiii) and convulxin(Bi-Biii), followed by incubation with PE-labeled anti-Pselectin antibody. The samples were analyzed by flow cytometry. Mean \pm SEM, $n=3$, NS = not significant, ${ }^{* * *} P<0.001$. One-way ANOVA followed by dunnett's multiple comparison test. (PDF $290 \mathrm{~kb}$ )

\section{Abbreviations}

CRP: Collagen-related triple-helical peptide; Gas6: Growth arrest-specific gene 6; GPVI: Glycoprotein VI; PAR1/4: Protease-activated receptors PAR1 and PAR4; PLCY2: Phospholipase Cy2; rhGas6: Recombinant human Gas6 protein; Syk: Spleen tyrosine kinase; TAM: Receptor tyrosine kinases, Tyro3, Axl and Mertk

\section{Funding}

This study was supported by grants from Natural Science Foundation of China (31201058, 81670133, 91539122, 81770138 and 91739302), Suzhou Science and Technology Project (SYS201674), the Priority Academic Program Development of Jiangsu Higher Education Institutions, and the collaboration fund from State Key Laboratory of Radiation Medicine and Protection (SS12800118).

\section{Authors' contributions}

JSZ designed the project, supervised the research, analyzed the data, and helped revise the manuscript. JSZ, AZY, YCW, FWC, ZZZ and VD performed research and collected and analyzed data. KSI, YO, RBB and QXL helped with manuscript writing and study design, and interpretation. YW designed the project, supervised the research, analyzed the data, and wrote the manuscript. JSZ and YW were responsible for funding acquisition. All authors read and approved the final manuscript.

Ethics approval and consent to participate Not applicable.

Consent for publication

Not applicable.

\section{Competing interests}

The authors declare that they have no competing interests.

\section{Publisher's Note}

Springer Nature remains neutral with regard to jurisdictional claims in published maps and institutional affiliations.

\footnotetext{
Author details

${ }^{1}$ Cyrus Tang Hematology Center, Collaborative Innovation Center of Hematology, State Key Laboratory of Radiation Medicine and Protection, Soochow University, Suzhou 215123, China. ${ }^{2}$ Department of Microbiology, Biochemistry and Molecular Genetics, Rutgers University-New Jersey Medical School, Newark, NJ, USA. ${ }^{3}$ Department of Clinical and Laboratory Medicine, Faculty of Medicine, University of Yamanashi, 1110 Shimokato, Chuo, Yamanashi 409-3898, Japan. ${ }^{4}$ Department of Ophthalmology and Visual Sciences, University of Louisville, Louisville, KY 40202, USA. ${ }^{5}$ The Sol Sherry Thrombosis Research Center, Temple University School of Medicine, 3420 North Broad Street, Philadelphia PA19140, USA.
} 
Received: 22 June 2018 Accepted: 25 November 2018 Published online: 12 December 2018

\section{References}

1. Lemke G. Biology of the TAM receptors. Cold Spring Harb Perspect Biol. 2013:5:a009076.

2. Nagata K, Ohashi K, Nakano T, Arita H, Zong C, Hanafusa H, Mizuno K. Identification of the product of growth arrest-specific gene 6 as a common ligand for Axl, sky, and Mer receptor tyrosine kinases. J Biol Chem. 1996;271: 30022-7.

3. Sasaki T, Knyazev PG, Cheburkin Y, Gohring W, Tisi D, Ullrich A, Timpl R, Hohenester E. Crystal structure of a C-terminal fragment of growth arrestspecific protein Gas6. Receptor tyrosine kinase activation by laminin G-like domains. J Biol Chem. 2002;277:44164-70.

4. Godowski PJ, Mark MR, Chen J, Sadick MD, Raab H, Hammonds RG Reevaluation of the roles of protein S and Gas6 as ligands for the receptor tyrosine kinase Rse/tyro 3. Cell. 1995:82:355-8.

5. Crosier KE, Crosier PS. New insights into the control of cell growth; the role of the Axl family. Pathology. 1997;29:131-5.

6. Chen J, Carey K, Godowski PJ. Identification of Gas6 as a ligand for Mer, a neural cell adhesion molecule related receptor tyrosine kinase implicated in cellular transformation. Oncogene. 1997;14:2033-9.

7. Mark MR, Chen J, Hammonds RG, Sadick M, Godowsk PJ. Characterization of Gas6, a member of the superfamily of $\mathrm{G}$ domain-containing proteins, as a ligand for Rse and Axl. J Biol Chem. 1996;271:9785-9.

8. Tanabe K, Nagata K, Ohashi K, Nakano T, Arita H, Mizuno K. Roles of gammacarboxylation and a sex hormone-binding globulin-like domain in receptorbinding and in biological activities of Gas6. FEBS Lett. 1997:408:306-10.

9. Manfioletti G, Brancolini C, Avanzi G, Schneider C. The protein encoded by a growth arrest-specific gene (gas6) is a new member of the vitamin $\mathrm{K}$ dependent proteins related to protein $\mathrm{S}$, a negative coregulator in the blood coagulation cascade. Mol Cell Biol. 1993;13:4976-85.

10. Goruppi S, Ruaro E, Schneider C. Gas6, the ligand of Axl tyrosine kinase receptor, has mitogenic and survival activities for serum starved NIH3T3 fibroblasts. Oncogene. 1996;12:471-80.

11. O'Donnell K, Harkes IC, Dougherty L, Wicks IP. Expression of receptor tyrosine kinase Axl and its ligand Gas6 in rheumatoid arthritis: evidence for a novel endothelial cell survival pathway. Am J Pathol. 1999;154:1171-80.

12. Goruppi S, Ruaro E, Varnum B, Schneider C. Gas6-mediated survival in $\mathrm{NIH} 3 \mathrm{~T} 3$ cells activates stress signalling cascade and is independent of Ras. Oncogene. 1999;18:4224-36.

13. Bellosta P, Zhang Q, Goff SP, Basilico C. Signaling through the ARK tyrosine kinase receptor protects from apoptosis in the absence of growth stimulation. Oncogene. 1997;15:2387-97.

14. Lee WP, Liao Y, Robinson D, Kung HJ, Liu ET, Hung MC. Axl-gas6 interaction counteracts E1A-mediated cell growth suppression and proapoptotic activity. Mol Cell Biol. 1999;19:8075-82.

15. D'Arcangelo D, Gaetano C, Capogrossi MC. Acidification prevents endothelial cell apoptosis by Axl activation. Circ Res. 2002;91:e4-12.

16. Nakano T, Higashino K, Kikuchi N, Kishino J, Nomura K, Fujita H, Ohara O, Arita $\mathrm{H}$. Vascular smooth muscle cell-derived, Gla-containing growthpotentiating factor for $\mathrm{ca}(2+)$-mobilizing growth factors. J Biol Chem. 1995; 270:5702-5.

17. Nakano T, Kawamoto K, Kishino J, Nomura K, Higashino K, Arita H. Requirement of gamma-carboxyglutamic acid residues for the biological activity of Gas6: contribution of endogenous Gas 6 to the proliferation of vascular smooth muscle cells. Biochem J. 1997;323(Pt 2):387-92.

18. Nakano T, Ishimoto Y, Kishino J, Umeda M, Inoue K, Nagata K, Ohashi K, Mizuno K, Arita H. Cell adhesion to phosphatidylserine mediated by a product of growth arrest-specific gene 6. J Biol Chem. 1997;272:29411-4

19. Fridell YW, Villa J Jr, Attar EC, Liu ET. GAS6 induces Axl-mediated chemotaxis of vascular smooth muscle cells. J Biol Chem. 1998;273:7123-6.

20. McCloskey P, Fridell YW, Attar E, Villa J, Jin Y, Varnum B, Liu ET. GAS6 mediates adhesion of cells expressing the receptor tyrosine kinase Axl. J Bio Chem. 1997;272:23285-91.

21. Avanzi GC, Gallicchio M, Bottarel F, Gammaitoni L, Cavalloni G, Buonfiglio D, Bragardo M, Bellomo G, Albano E, Fantozzi R, et al. GAS6 inhibits granulocyte adhesion to endothelial cells. Blood. 1998:91:2334-40.

22. Wu Y, Singh S, Georgescu MM, Birge RB. A role for Mer tyrosine kinase in alphavbeta5 integrin-mediated phagocytosis of apoptotic cells. J Cell Sci. 2005; 118:539-53.
23. Angelillo-Scherrer A, de Frutos P, Aparicio C, Melis E, Savi P, Lupu F, Arnout J. Dewerchin M, Hoylaerts M, Herbert J, et al. Deficiency or inhibition of Gas6 causes platelet dysfunction and protects mice against thrombosis. Nat Med. 2001;7:215-21.

24. Angelillo-Scherrer $A$, Burnier $L$, Flores $N$, Savi $P$, DeMol M, Schaeffer $P$, Herbert JM, Lemke G, Goff SP, Matsushima GK, et al. Role of Gas6 receptors in platelet signaling during thrombus stabilization and implications for antithrombotic therapy. J Clin Invest. 2005;115:237-46.

25. Chen C, Li Q, Darrow AL, Wang Y, Derian CK, Yang J, de Garavilla L, Andrade-Gordon P, Damiano BP. Mer receptor tyrosine kinase signaling participates in platelet function. Arterioscler Thromb Vasc Biol. 2004;24: 1118-23.

26. Sather S, Kenyon KD, Lefkowitz JB, Liang X, Varnum BC, Henson PM, Graham DK. A soluble form of the Mer receptor tyrosine kinase inhibits macrophage clearance of apoptotic cells and platelet aggregation. Blood. 2007;109:1026-33.

27. Cosemans JM, Van Kruchten R, Olieslagers S, Schurgers $L$, Verheyen FK, Munnix IC, Waltenberger J, Angelillo-Scherrer A, Hoylaerts MF, Carmeliet P, Heemskerk JW. Potentiating role of Gas6 and Tyro3, AxI and Mer (TAM) receptors in human and murine platelet activation and thrombus stabilization. J Thromb Haemost. 2010;8:1797-808.

28. Gould WR, Baxi SM, Schroeder R, Peng YW, Leadley RJ, Peterson JT, Perrin LA. Gas6 receptors Axl, sky and Mer enhance platelet activation and regulate thrombotic responses. J Thromb Haemost. 2005;3:733-41.

29. Lu Q, Gore M, Zhang Q, Camenisch T, Boast S, Casagranda F, Lai C, Skinner MK, Klein R, Matsushima GK, et al. Tyro-3 family receptors are essential regulators of mammalian spermatogenesis. Nature. 1999;398:723-8.

30. Wu Y, Suzuki-Inoue K, Satoh K, Asazuma N, Yatomi Y, Berndt MC, Ozaki Y. Role of fc receptor $Y$-chain in platelet glycoprotein $\mathrm{lb}$-mediated signaling. Blood. 2001;97:3836-45.

31. Wu Y, Asazuma N, Satoh K, Yatomi Y, Takafuta T, Berndt MC, Ozaki Y. Interaction between von Willebrand factor and glycoprotein lb activates Src kinase in human platelets: role of phosphoinositide 3-kinase. Blood. 2003: 101:3469-76.

32. Wu Y, Ahmad SS, Zhou J, Wang L, Cully MP, Essex DW. The disulfide isomerase ERp57 mediates platelet aggregation, hemostasis and thrombosis. Blood. 2012;119:1737-46.

33. Zhou J, Wu Y, Wang L, Rauova L, Hayes VM, Poncz M, Essex DW. The disulfide isomerase ERp57 is required for fibrin deposition in vivo. J Thromb Haemost. 2014;12:1890-7.

34. Stalker TJ, Traxler EA, Wu J, Wannemacher KM, Cermignano SL, Voronov R, Diamond SL, Brass LF. Hierarchical organization in the hemostatic response and its relationship to the platelet-signaling network. Blood. 2013;121:1875-85.

35. Greene TK, Wang C, Hirsch JD, Zhai L, Gewirtz J, Thornton MA, Miao HZ, Pipe SW, Kaufman RJ, Camire RM, et al. In vivo efficacy of platelet-delivered, high specific activity factor VIII variants. Blood. 2010;116:6114-22.

36. Zhou J, Wu Y, Wang L, Rauova L, Hayes VM, Poncz M, Essex DW. The Cterminal CGHC motif of protein disulfide isomerase supports thrombosis. J Clin Invest. 2015;125:4391-406

37. Zhou J, Wu Y, Chen F, Wang L, Rauova L, Hayes VM, Poncz M, Li H, Liu T, Liu J, Essex DW. The disulfide isomerase ERp72 supports arterial thrombosis in mice. Blood. 2017;130:817-28.

38. Kim K, Hahm E, Li J, Holbrook LM, Sasikumar P, Stanley RG, Ushio-Fukai M, Gibbins JM, Cho J. Platelet protein disulfide isomerase is required for thrombus formation but not for hemostasis in mice. Blood. 2013;122:1052-61.

39. Nieswandt B, Brakebusch C, Bergmeier W, Schulte V, Bouvard D, MokhtariNejad R, Lindhout T, Heemskerk JW, Zirngibl H, Fassler R. Glycoprotein VI but not alpha2beta1 integrin is essential for platelet interaction with collagen. EMBO J. 2001;20:2120-30.

40. Holtkotter O, Nieswandt B, Smyth N, Muller W, Hafner M, Schulte V, Krieg T, Eckes B. Integrin alpha 2-deficient mice develop normally, are fertile, but display partially defective platelet interaction with collagen. J Biol Chem. 2002;277:10789-94.

41. Nieswandt B, Watson SP. Platelet-collagen interaction: is GPVI the central receptor? Blood. 2003;102:449-61.

42. Sarratt KL, Chen H, Zutter MM, Santoro SA, Hammer DA, Kahn ML. GPVI and alpha2beta1 play independent critical roles during platelet adhesion and aggregate formation to collagen under flow. Blood. 2005;106:1268-77.

43. Asselin J, Gibbins JM, Achison M, Lee YH, Morton LF, Farndale RW, Barnes MJ, Watson SP. A collagen-like peptide stimulates tyrosine phosphorylation of syk and phospholipase C gamma2 in platelets independent of the integrin alpha2beta1. Blood. 1997;89:1235-42. 
44. Niedergang F, Alcover A, Knight CG, Farndale RW, Barnes MJ, Francischetti IM, Bon C, Leduc M. Convulxin binding to platelet receptor GPVI: competition with collagen related peptides. Biochem Biophys Res Commun. 2000;273:246-50.

45. Vargaftig BB, Prado-Franceschi J, Chignard M, Lefort J, Marlas G. Activation of Guinea-pig platelets induced by convulxin, a substance extracted from the venom of Crotalus durissus cascavella. Eur J Pharmacol. 1980;68:451-64.

46. Tsuji M, Ezumi Y, Arai M, Takayama H. A novel association of fc receptor gamma-chain with glycoprotein $\mathrm{Vl}$ and their co-expression as a collagen receptor in human platelets. J Biol Chem. 1997;272:23528-31.

47. Ichinohe T, Takayama H, Ezumi Y, Arai M, Yamamoto N, Takahashi H, Okuma M. Collagen-stimulated activation of Syk but not c-Src is severely compromised in human platelets lacking membrane glycoprotein VI. J Biol Chem. 1997;272:63-8.

48. Ezumi Y, Shindoh K, Tsuji M, Takayama H. Physical and functional association of the Src family kinases Fyn and Lyn with the collagen receptor glycoprotein VI-fc receptor gamma chain complex on human platelets. J Exp Med. 1998;188:267-76.

49. Falet H, Barkalow KL, Pivniouk VI, Barnes MJ, Geha RS, Hartwig JH. Roles of SLP-76, phosphoinositide 3-kinase, and gelsolin in the platelet shape changes initiated by the collagen receptor GPVI/FcR gamma-chain complex. Blood. 2000:96:3786-92.

50. Pasquet JM, Gross B, Quek L, Asazuma N, Zhang W, Sommers CL, Schweighoffer $E$, Tybulewicz $V$, Judd $B$, Lee JR, et al. LAT is required for tyrosine phosphorylation of phospholipase cgamma2 and platelet activation by the collagen receptor GPVI. Mol Cell Biol. 1999;19:8326-34.

51. Mangin P, Nonne C, Eckly A, Ohlmann P, Freund M, Nieswandt B, Cazenave JP, Gachet C, Lanza F. A PLC gamma 2-independent platelet collagen aggregation requiring functional association of GPVI and integrin alpha2beta1. FEBS Lett. 2003;542:53-9.

52. Bellosta P, Costa M, Lin DA, Basilico C. The receptor tyrosine kinase ARK mediates cell aggregation by homophilic binding. Mol Cell Biol. 1995;15: 614-25.

53. Heiring C, Dahlback B, Muller YA. Ligand recognition and homophilic interactions in Tyro3: structural insights into the Axl/Tyro3 receptor tyrosine kinase family. J Biol Chem. 2004;279:6952-8.

54. Clauser S, Bachelot-Lozat C, Fontana P, Gaussem P, Remones V, Aiach M, Borgel D. Physiological plasma Gas6 levels do not influence platelet aggregation. Arterioscler Thromb Vasc Biol. 2006;26:e22

55. Taylor IC, Roy S, Varmus HE. Overexpression of the sky receptor tyrosine kinase at the cell surface or in the cytoplasm results in ligand-independent activation. Oncogene. 1995;11:2619-26.

56. Hubbard TJ, Murzin AG, Brenner SE, Chothia C. SCOP: a structural classification of proteins database. Nucleic Acids Res. 1997;25:236-9.

57. Kasper C, Rasmussen H, Kastrup JS, Ikemizu S, Jones EY, Berezin V, Bock E, Larsen IK. Structural basis of cell-cell adhesion by NCAM. Nat Struct Biol. 2000; 7:389-93

58. Kostrewa D, Brockhaus M, D'Arcy A, Dale GE, Nelboeck P, Schmid G, Mueller F, Bazzoni G, Dejana E, Bartfai T, et al. X-ray structure of junctional adhesion molecule: structural basis for homophilic adhesion via a novel dimerization motif. EMBO J. 2001;20:4391-8.

59. Tsou WI, Nguyen KQ, Calarese DA, Garforth SJ, Antes AL, Smirnov SV, Almo SC, Birge RB, Kotenko SV. Receptor tyrosine kinases, TYRO3, AXL, and MER, demonstrate distinct patterns and complex regulation of ligand-induced activation. J Biol Chem. 2014;289:25750-63.

60. Kasikara C, Kumar S, Kimani S, Tsou WI, Geng K, Davra V, Sriram G, Devoe C, Nguyen KN, Antes A, et al. Phosphatidylserine sensing by TAM receptors regulates AKT-dependent Chemoresistance and PD-L1 expression. Mol Cancer Res. 2017;15:753-64.

Ready to submit your research? Choose BMC and benefit from:

- fast, convenient online submission

- thorough peer review by experienced researchers in your field

- rapid publication on acceptance

- support for research data, including large and complex data types

- gold Open Access which fosters wider collaboration and increased citations

- maximum visibility for your research: over $100 \mathrm{M}$ website views per year

At BMC, research is always in progress.

Learn more biomedcentral.com/submissions 